\title{
Jaritmatika : Pengaruhnya pada Kemampuan Berhitung Tunagrahita
}

\author{
Salma Nur Saida \\ Fakultas Psikologi Universitas Muhammadiyah Malang
}

DOI: http://doi.org/10.29080/jpp.v12i2.638

\begin{abstract}
Jarimatika is a method used for math operations in addition, subtraction, multiplication, and division. This research aims to study the effectiveness of Jarimatika to improve the math operations among mentally retarded students at SLB C Putera Asih, Kediri. This study uses a quantitativeexperimental method with a single-case design. There are 7 students with mental retardation in grade 2 junior high school then 2 students as a sample used having low levels in operation. Data collection techniques used the achievement test. Descriptive data are presented in tables and line graphs to show the progress of the intervention. The results showed that there were increasing scores in addition, subtraction, and multiplication. In the other words, the Jarimatika was effective in improving math operation among mentally retarded students.
\end{abstract}

Keyword : jarimatika, tunagrahita, operation

\begin{abstract}
Abstrak : Jarimatika merupakan suatu cara yang digunakan untuk operasi hitung tambah, kurang, kali, dan bagi dengan menggunakan jari dan ruas-ruas jari tangan. Penelitian ini bertujuan untuk mengetahui efektivitas metode jarimatika untuk meningkatkan kemampuan berhitung siswa tunagrahita kategori ringan di SLB C Putera Asih Kota Kediri. Penelitian ini menggunakan metode kuantitatif-eksperimen. Desain penelitian yang digunakan adalah yaitu single-case experimental design. Populasi tunagrahita ringan kelas 2 SMP berjumlah 7 orang sedangkan sampel yang digunakan berjumlah 2 siswa dengan tingkat kemampuan berhitung yang rendah. Teknik pengumpulan data dengan menggunakan achievement test. Data deskriptif disajikan dalam bentuk tebel dan grafik garis untuk menunjukkan progress intervensi. Hasil penelitian menunjukkan bahwa hasil tes kemampuan berhitung penjumlahan, pengurangan, dan perkalian pada siswa mengalami peningkatan skor nilai. Dengan kata lain metode jarimatika menunjukkan efektif dalam meningkatkan kemampuan berhitung pada siswa tunagrahita.
\end{abstract}

Kata kunci : jarimatika, tunagrahita, berhitung

Corresponding Author: Salma Nur Saida (e-mail: saidasalma35@gmail.com) Fakultas Psikologi Universitas Muhammadiyah Malang, Jl. Bendungan Sutami No.188, Sumbersari, Kec. Lowokwaru, Kota Malang, Jawa Timur 65145 


\section{Pendahuluan}

Tunagrahita ditandai dengan keadaan abnormalitas psikologis, fisiologis, dan anatomis sehingga mengalami keterlambatan keterampilan selama masa perkembangan. Anak tunagrahita memiliki tingkat kecerdasan yang rendah atau bahkan di bawah angka normal dengan IQ berkisar antara 50 sampai dengan 69 sehingga membutuhkan bantuan atau pelayanan secara khusus, termasuk pendidikan dan bimbingan (Maslim, 2013). Salah satu perkembangan anak tunagrahita yang memerlukan bantuan adalah kemampuan berhitung baik penjumlahan, pengurangan, perkalian, dan pembagian (effendi, 2006).

Berhitung adalah pelajaran yang bersifat abstrak yang sulit dipahami oleh anak tunagrahita sehingga peran guru sangat penting untuk menggunakan metode yang cocok (Padmodisastro, 2001). Pada siswa normal, kemampuan kognitif berada pada tahap operasional konkrit dimana siswa berpikir berdasarkan pengalaman yang mereka peroleh secara langsung melalui benda-benda konkrit. Adapun siswa tunagrahita mengalami hambatan pada perkembangan kognitifnya yang mengakibatkan mereka kurang mampu berpikir dengan abstrak, sulit menerima perintah yang rumit serta sering lupa (Suharmini, 2007). Dengan adanya keterbatasan yang dimiliki oleh siswa tunagrahita, maka pemilihan metode yang digunakan juga sangat berpengaruh untuk menunjang kemampuan berhitungnya.

Jarimatika merupakan metode berhitung dalam operasi penjumlahan, pengurangan, perkalian, dan pembagian dengan menggunakan alat bantu jari (Susanto, 2011). Dibandingkan dengan metode yang lainnya, jarimatika lebih menekankan pada penguasaan konsep terlebih dahulu kemudian cara cepatnya, sehingga siswa akan menguasai ilmu secara matang. Selain itu, metode ini disampaikan secara menyenangkan sehingga anak-anak akan merasa senang dan mudah menerimanya (Abdullah, 2009). Fleksibel, tidak perlu membeli alat, tidak memberatkan memori otak saat digunakan, tidak bisa disita saat ujian berlangsung, dan menunjukkan tingkat keakuratan yang tinggi dalam proses perhitungan merupakan sejumlah kelebihan metode Jarimatika (Wulandari, 2008). Selain itu siswa juga terlibat secara fisik, lisan, maupun tulisan karena gerakan jari-jari tangan menarik minat anak (Prasetyo, 2011). Adapun kekurangan dari metode jarimatika adalah rumus-rumus yang harus dipahami oleh siswa.

Langkah-langkah penggunaan metode jarimatika Jika dalam operasi penjumlahan dan pengurangan dimulai dengan penyebutan bilangan dengan jari telunjuk kanan sebagai bilangan awal (satuan) dan jari kiri sebagai puluhan. Dalam perkalian dan pembagian penyebutan bilangan dimulai dari jari kelingking sebagai bilangan terkecil dan ibu jari sebagai bilangan terbesar. Ini untuk membedakan antara operasi penjumlahan dan pengurangan dengan operasi perkalian dan pembagian (Prasetyo, 2013). Bilanganbilangan pada operasi perkalian dan pembagian ini terbagi dalam kelompok-kelompok besar misalnya kelas 6 s/d 10, 11 s/d 15, 16 s/d 20, dan seterusnya. Sedangkan, penyebutan bilangan pada masing-masing jari tidak selalu sama, tetapi disesuaikan dengan kelas-kelas misalnya pada kelas $6 \mathrm{~s} / \mathrm{d} 10$ jari kelingking mempunyai nilai 6, jari manis memiliki nilai 7 , dan seterusnya. Demikian pula dengan metode perhitungan dan rumus penerapan tergantung pada kelas dimana operasi itu berlangsung.

Berdasarkan observasi yang peneliti lakukan di SLB C "Putera Asih" Kota Kediri, guru mengajarkan berhitung menggunakan metode ceramah dengan alat bantu sempoa dan itu kurang efektif untuk siswa tunagrahita. Dengan adanya hambatan di atas, dibutuhkan metode pembelajaran yang tepat. Untuk meningkatkan kemampuan siswa tunagrahita maka diperlukan strategi guru agar mereka memiliki kemampuan berhitung yang baik. Salah satu metode pembelajaran yang sesuai dengan siswa tunagrahita adalah jarimatika. Metode ini disampaikan secara fun sehingga membuat anak-anak tunagrahita merasa senang (Wulandari, 2008). Berdasarkan uraian permasalahan di atas, peneliti 
ingin melihat bagaimana efektivitas metode jarimatika untuk meningkatkan kemampuan berhitung siswa tunagrahita kategori ringan di SLB C "Putera Asih" Kota Kediri.

\section{Metode Penelitian}

Penelitian ini menggunakan desain eksperimental kasus tunggal (single-case experimental design) dengan variabel X (Metode Jarimatika) dan variable Y (Kemampuan Berhitung). Eksperimental kasus tunggal merupakan desain penelitian yang digunakan untuk mengevaluasi efek suatu perlakuan (intervensi) dengan kasus tunggal. Kasus tunggal dapat berupa beberapa subjek dalam satu kelompok atau subjek yang diteliti adalah tunggal $(\mathrm{N}=1)$ (Latipun, 2011). Dalam penelitian ini, peneliti melakukan pengukuran yang sama dan berulang-ulang untuk mengetahui seberapa banyak perubahan yang terjadi dari hari ke hari. Peneliti memilih desain ini karena yang ditekankan dalam penelitian ini adalah efek terapi atau perlakuan. Pola desain penelitian eksperimental yang digunakan adalah A-B-A withdrawal. Desain A-B-A withdrawal pada dasarnya melibatkan fase baseline (A) dan fase perlakuan (B). Withdrawal design adalah meniadakan perlakuan yang diberikan kepada subjek untuk melihat apakah perlakuan tersebut efektif atau tidak.

Tabel 1

Desain Eksperimental Kasus Tunggal (Single-Case Experimental Design) A-B-A Withdrawal

\begin{tabular}{ccc}
\hline Baseline & Intervensi & Withdrawal \\
\hline Fase A & Fase B & Fase A \\
\hline
\end{tabular}

Dalam desain eksperimental ini, sebuah perilaku diukur (baseline), sebuah perlakuan diintroduksikan (intervensi), dan kemudian intervensi tersebut ditiadakan (withdrawal). Selanjutnya perilaku tersebut diukur berulang-ulang untuk melihat efek dari pemberian perlakuan. Tujuan digunakannya pola desain A-B-A dalam penelitian ini ialah untuk mengetahui seberapa efektifkah metode jarimatika terhadap kemampuan anak tunagrahita dalam berhitung. Statistik deskriptif akan digunakan untuk menampilkan data yang telah terkumpul tanpa bermaksud untuk membuat kesimpulan (Sugiyono, 2010). Penyajian data berupa rangkuman hasil tes kemampuan berhitung disajikan dalam bentuk grafik garis.

\section{Hasil Penelitian}

Pada analisis hasil tes kemampuan berhitung dapat dilihat hasil perolehan skor kemampuan berhitung kedua subjek pada tahap baseline A1 (sebelum metode jarimatika diberikan). Berikut adalah data hasil tes kemampuan berhitung subjek CFF pada fase baseline A1.

Tabel 2

Data Hasil Tes Kemampuan Berhitung Subjek CFF pada Fase Baseline

\begin{tabular}{cccc}
\hline Fase & Sesi & Skor & Pencapaian \\
\hline \multirow{3}{*}{ Baseline A1 } & 1 & 40 & $33 \%$ \\
& 2 & 28 & $20 \%$ \\
& 3 & 46 & $40 \%$ \\
& 4 & 30 & $13 \%$ \\
\hline
\end{tabular}

Pada tahap baseline A1 sesi 1, subjek CFF mampu mengerjakan 5 butir soal dengan benar dari 15 jumlah soal butir dan mendapatkan skor 40. Pada sesi 2, subjek mampu mengerjakan 3 butir dengan benar dan mendaptkan skor 28. Selanjutnya sesi 3 , subjek 
mampu mengerjakan dengan benar 6 butir soal dengan skor 46. Akhirnya pada sesi 4 , subjek mampu mengerjakan dengan benar 2 butir soal dengan skor 30. baseline A.

Selanjutnya adalah data hasil tes kemampuan berhitung subjek EN pada fase

Tabel 3

Data Hasil Tes Kemampuan Berhitung Subjek EN pada Fase Baseline A1

\begin{tabular}{cccc}
\hline Fase & Sesi & Skor & Pencapaian \\
\hline \multirow{3}{*}{ Baseline A1 } & 1 & 40 & $13 \%$ \\
& 2 & 28 & $20 \%$ \\
& 3 & 46 & $26 \%$ \\
\hline
\end{tabular}

Pada tahap baseline A1 sesi 1, subjek mampu mengerjakan dengan benar 2 butir dari 15 soal sehingga mendapatkan skor 22. Pada sesi 2, subjek mampu mengerjakan dengan benar 3 butir dengan skor 28. Berikutnya pada sesi 3, subjek mampu mengerjakan dengan benar 4 butir dengan skor 34 dan terakhir sesi 4 , subjek mengerjakan 4 butir dengan benar dan mendapatkan skor 34 .

Fase kedua adalah kondisi intervensi/perlakuan dimana subjek diberikan perlakuan berupa penerapan jarimatika kemudian dilakukan pengukuran lagi dengan tujuan untuk mendapatkan data progress (Sunanto, 2006). Berikut adalah data hasil tes kemampuan berhitung subjek CFF pada fase Intervesi:

Tabel 4

\begin{tabular}{cccc} 
Data Hasil Tes Kemampuan Berhitung Fase Intervensi Subjek CFF \\
\hline Fase & Sesi & Skor & Pencapaian \\
\hline 1 & 70 & $66 \%$ \\
2 & 76 & $73 \%$ \\
3 & 64 & $60 \%$ \\
4 & 76 & $73 \%$ \\
Intervensi & 5 & 88 & $86 \%$ \\
& 6 & 76 & $73 \%$ \\
& 7 & 82 & $80 \%$ \\
8 & 82 & $80 \%$ \\
9 & 88 & $86 \%$ \\
& 10 & 88 & $86 \%$ \\
\hline
\end{tabular}

Pada tahap intervensi sesi 1 , subjek mampu mengerjakan 10 butir soal dan mendapatkan skor 70. Pada sesi 2, subjek mendapatkan skor 76 dari 11 soal yang dikerjakan, sesi 3 skor 64 dari 9 soal, sesi 4 subjek mendapatkan skor 76 dari 11 soal, sesi mengerjakan 13 soal dengan nilai 88, sesi 6 sebanyak 11 butir dengan skor 76, sesi 7 sebanyak 12 soal dengan skor 82 , sesi 8 sebanyak 12 soal dengan skor 82 , sesi 9 sebanyak 13 soal dengan skor 88 dan sesi terakhir sesi 10 subjek mampu mengerjakan 13 soal dan mendapatkan skor 88.

Pada tahap intervensi sesi 1, subjek EN mampu mengerjakan soal sebanyak 10 butir dan mendapatkan skor 70. Pada sesi 2, subjek mampu mengerjakan 13 soal dengan skor 88 , sesi 3 sebanyak 13 soal dengan skor 88 , sesi 4 sebanyak 11 soal dengan skor 76 , sesi 5 dengan 13 soal dan skor 88. Selanjutnya pada sesi 6 subjek mampu mengerjakan soal 7 soal dengan skor 52 , sesi 7 sebanyak 11 soal dengan skor 76, sesi 8 ada 12 soal dan skor 82, sesi 9 sebanyak 13 butir dengan skor 88, dan sesi 10 sebanyak 13 soal dengan skor 88. 
Tabel 5

Data Hasil Tes Kemampuan Berhitung Penjumlahan, Pengurangan, dan Perkalian Fase Intervensi Subjek EN

\begin{tabular}{cccc}
\hline Fase & Sesi & Skor & Pencapaian \\
\hline 1 & 70 & $66 \%$ \\
\hline 2 & 76 & $86 \%$ \\
\hline 3 & 64 & $86 \%$ \\
\hline \multirow{3}{*}{ Intervensi } & 4 & 76 & $73 \%$ \\
\cline { 2 - 4 } & 5 & 88 & $86 \%$ \\
\cline { 2 - 4 } & 6 & 76 & $46 \%$ \\
\hline 7 & 82 & $73 \%$ \\
& 7 & 82 & $80 \%$ \\
\hline 9 & 88 & $86 \%$ \\
\hline & 10 & 88 & $86 \%$ \\
\hline
\end{tabular}

Selanjutnya pada fase baseline A2, yaitu setelah subjek mendapatkan perlakuan berupa metode jarimatika. Hal ini bertujuan untuk melihat apakah perlakuan yang diberikan efektif atau tidak (Sunanto, 2006). Berikut adalah data hasil tes kemampuan berhitung subjek CFF pada fase baseline A2:

Tabel 6

Data Hasil Tes Kemampuan Berhitung Fase Baseline A2 Subjek CFF

\begin{tabular}{cccc}
\hline Fase & Sesi & Skor & Pencapaian \\
\hline Baseline A2 & 1 & 88 & $86 \%$ \\
\cline { 2 - 4 } & 2 & 88 & $86 \%$ \\
\cline { 2 - 4 } & 3 & 94 & $93 \%$ \\
\cline { 2 - 4 } & 4 & 88 & $86 \%$ \\
\hline
\end{tabular}

Pada tahap baseline A2 sesi 1, subjek mampu mengerjakan soal sebanyak 13 butir dan mendapatkan skor 88, sesi 2 sebanyak 13 butir dengan skor 88, sesi 3 mengerjakan 14 soal dan mendapatkan skor 94 , dan sesi 4 sebanyak 13 butir dan mendapatkan skor 88. Selanjutnya adalah data hasil tes kemampuan berhitung subjek EN pada fase baseline A2.

Tabel 7

Data Hasil Tes Kemampuan Berhitung Fase Baseline A2 Subjek EN

\begin{tabular}{cccc}
\hline Fase & Sesi & Skor & Pencapaian \\
\hline Baseline A2 & 1 & 88 & $86 \%$ \\
\hline & 2 & 88 & $93 \%$ \\
\cline { 2 - 4 } & 3 & 94 & $86 \%$ \\
\cline { 2 - 4 } & 4 & 88 & $86 \%$ \\
\hline
\end{tabular}

Pada tahap baseline A2 sesi 1, subjek EN mampu mengerjakan 13 soal dan mendapatkan skor 88, sesi 2 sebanyak 14 soal dengan skor 94, sesi 3 sebanyak 13 soal dengan skor 88, dan sesi 4 mampu mengerjakan 13 soal dan mendapatkan skor 88 . Kedua subjek menunjukkan data masing-masing yang dapat dilihat pada grafik berikut. 


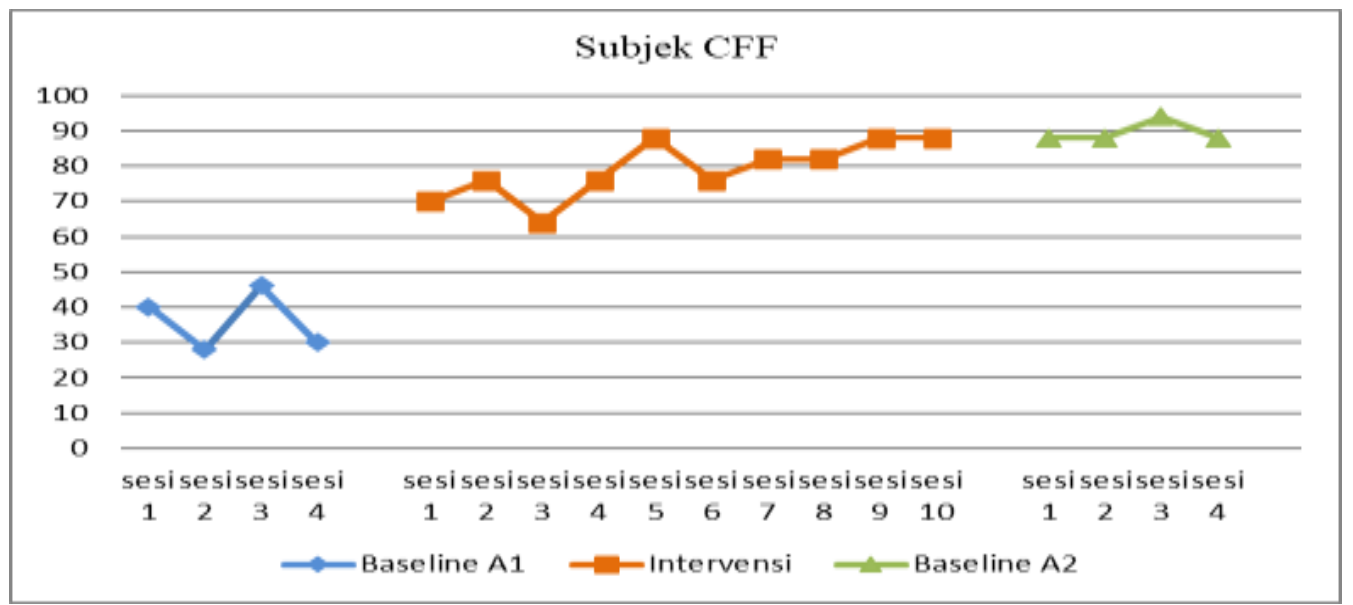

Gambar 1. Grafik Nilai Skor Peningkatan Kemampuan Berhitung dengan Metode Jarimatika

Pada tahap baseline A1 sesi 1, subjek mampu mengerjakan 5 butir soal dengan benar dari total 15 soal sehingga mendapatkan skor 40. Selanjutnya diikuti sesi 2 dengan skor 28, sesi 3 skor 46, dan sesi 4 skor 30. Adapun pada tahap intervensi sesi 1 subjek mampu mengerjakan soal sebanyak 10 butir dan mendapatkan skor sebanyak 70 . Pada sesi berikutnya berturut-turut sesi 2 skor 76, sesi 3 skor 64 , sesi 4 skor 76, sesi 5 skor 88, sesi 6 skor 76, sesi 7 skor 82 , sesi 8 skor 82, sesi 9 skor 88, dan sesi 10 skor 88 . Pada tahap baseline A2 datanya terlihat pada sesi 1 subjek mampu mengerjakan 13 soal dengan skor 88, sesi 2 skor 88, sesi 3 skor 94, dan sesi 4 skor 88.

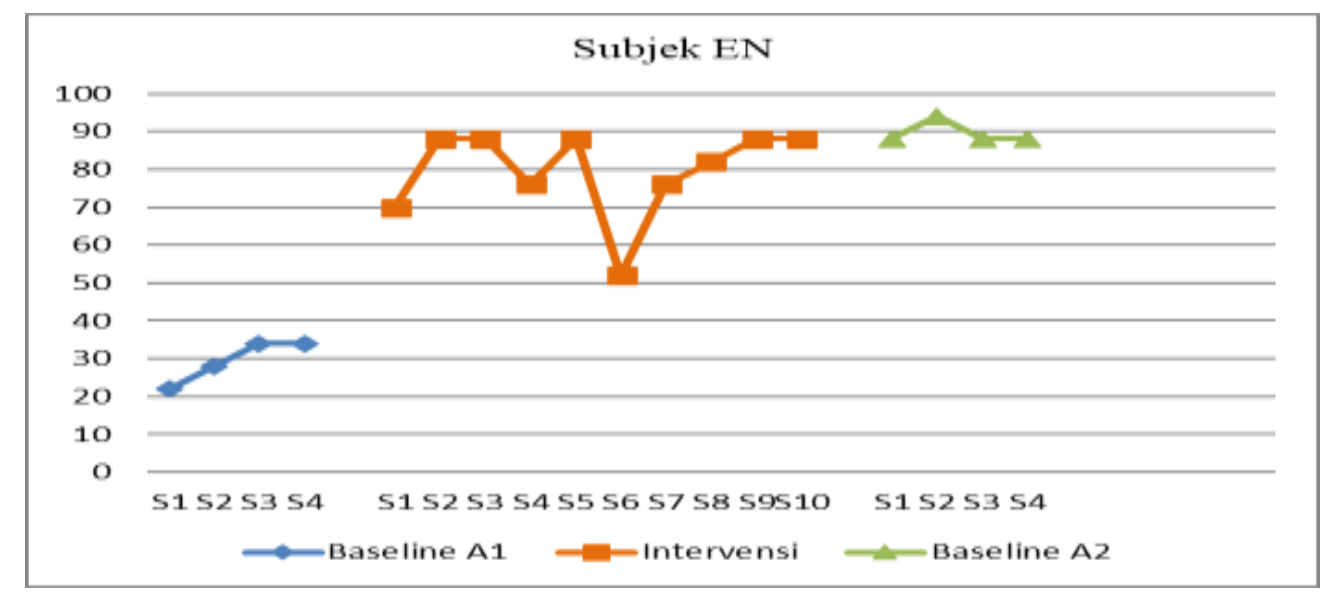

Gambar 2. Grafik Nilai Skor Kemampuan Berhitung Setelah Menggunakan Jarimatika

Pada tahap baseline A1 sesi 1, subjek mampu mengerjakan dengan benar 2 butir soal sebanyak 15 butir dan mendapatkan skor sebanyak 22. Pada sesi 2 subjek mampu mengerjakan 3 soal dengan skor 28, sesi 3 sebanyak 4 soal dengan skor 34 , dan sesi 4 sebanyak 4 soal dengan skor 34 . Pada tahap intervensi sesi 1 subjek mampu mengerjakan 10 soal dengan skor 70 , sesi 2 sebanyak 13 soal dengan skor, sesi 3 sebanyak 13 soal dengan skor 88, sesi 4 sebanyak 11 soal dengan skor 76, sesi 5 sebanyak 13 soal dengan skor 88, sesi 6 sebanyak 7 soal dengan skor 52, sesi 7 sebanyak 11 soal dengan skor 76, sesi 8 sebanyak 12 soal dengan skor 82 , sesi 9 sebanyak 13 soal dengan skor 88 dan sesi 10 sebanyak 13 soal dengan skor 88 . Adapun pada tahap baseline A2 sesi 1 subjek mampu mengerjakan 13 soal dengan skor 88 , sesi 2 sebanyak 14 soal dengan skor 94, sesi 3 sebanyak 13 soal dengan skor 88 , dan sesi 4 sebanyak 13 soal dengan skor 88 . 
Secara keseluruhan dengan meningkatnya total skor hasil tes kemampuan berhitung pada subjek pada kedua subjek sesi A1- intervensi - A2, data ini menunjukkan efektivitas intervensi sangat baik terhadap peningkatan kemampuan belajar berhitung penjumlahan, pengurangan, dan perkalian.

\section{Pembahasan}

Hasil tes kemampuan berhitung kedua subjek pada fase baseline A1, intervensi, dan baseline A2 secara keseluruhan meningkat. Hasil pencapaian pada baseline A1 antara $10 \%$ sampai $40 \%$, fase intervensi antara $46 \%$ sampai $86 \%$, sedangkan fase A2 antara $86 \%$ sampai $93 \%$. Hal ini menunjukan peningkatan yang signifikan dalam setiap fase. Dari diskriptif data yang ditampilkan terlihat ada pengaruh penerapan metode jarimatika terhadap kemampuan berhitung siswa. Sesuai dengan teori efektivitas metode pembelajaran bahwa suatu program dikatakan efektif apabila dapat mencapai tujuan yang telah ditetapkan (Ibrahim, 2003). Hasil penelitian ini sesuai dengan penelitian sebelumnya yang juga melihat jarimatika efektif untuk meningkatkan hasil belajar matematika (Sutrisno, 2010). Jarimatika efektif meningkatkan kemampuan penjumlahan dan pengurangan sederhana (Irmana, 2016).

Pada saat intervensi dengan menerapkan jarimatika siswa diajari pemahaman secara benar tentang konsep bilangan, lambang bilangan, dan operasi hitung dasar selanjutnya cara berhitung dengan jari-jari tangan. Jarimatika memberikan visualisasi proses berhitung yang menyenangkan saat belajar matematika. Sutrisno (2010) mengatakan bahwa pembelajaran yang dilakukan secara menyenangkan akan membuat sistem limbik di otak anak senantiasa terbuka sehingga memudahkan anak dalam menerima materi baru, membiasakan anak mengembangkan otak kanan dan kiri serta membuat otak bekerja lebih optimal. Hasil dalam penelitian ini menunjukan bahwa jarimatika merupakan sebuah metode yang dilakukan dengan permaian yang menyenangkan, suasana belajar yang menggembirakan dan menarik untuk anak (Yus, 2011).

Di dalam penelitian ini metode jarimatika efektif digunakan untuk membantu siswa tunagrahita ringan karena dilakukan dengan menyenangkan. Ukhana (2011) menegaskan bahwa jika siswa merasa nyaman dalam belajar maka akan ada peningkatan motivasi dan hasil belajar serta mendayagunaan potensi kognitif, afektif dan psikomotor siswa secara optimal. Selain itu penerapan metode pembelajaran jarimatika ini juga dikombinasikan dengan metode lainnya seperti pemberian tugas, demonstrasi, tanya jawab, mengucapkan syair, bercakap-cakap, bercerta, praktek langsung, percobaan atau eksperimen. Pengkombinasian metode tersebut disesuaikan dengan kebutuhan dan kemampuan anak pada saat diberikannya pelajaran dan metode ini merupakan salah satu cara yang efektif untuk mendapatkan hasil belajar yang optimal (Wulandari, 2008).

\section{Simpulan dan Saran}

Berdasarkan hasil penelitian dan penjelasan yang telah diuraikan diatas, dapat disimpulkan bahwa penerapan metode jarimatika efektif meningkatkan kemampuan berhitung pada siswa tunagrahira kategori ringan. Proses pembelajaran yang menyenangkan membuat mereka dapat menerapkan tahapan jarimatika yang diajarkan. Kedua subjek yang dilibatkan mampu mengalami proses pembelajaran dengan tahapan yang ditatpkan serta menunjukkan peningkatan hasil belajar setelah melewati fase intervensi. Selain kemampuan berhitung yang terlihat pada setiap fase, subjek juga menunjukkan adanya peningkatan motivasi belajar. Mereka merasa senang selama mengikuti proses pembelajaran karena melibatkan motorik jari mereka. Penerapan jarimatika mungkin bisa dikombinasikan dengan metode lainnya seperti pemberian tugas, 
demonstrasi, tanya jawab, mengucapkan syair, bercakap-cakap, bercerita, praktek langsung, dan percobaan sederhana. Selanjutnya penelitian selanjutnya bisa membandingkan jarimatika dengan metode lain agar dapat memperkaya para guru dengan ide metode pembelajaran khususnya untuk belajar matematika.

\section{Daftar Pustaka}

Abraham, N., Mathias, J., \& Williams. S. (2014). A study to assess the knowledge and effect of nomophobia among students of selected degree college in Mysore. Asian Journal of Nursing Education and Research 4(4), 421-428. http://dx.doi.org/10.5958/2454-2660.2019.00075.9

Aggarwal, M., Basu, D., \& Grover, S. (2012). Mobile phone use by resident doctor: Tendecy to addiction-like behaviour. German Journal of Psychiatry, 15(2) 50-55

Argumosa-Villar, L., Boada-Grau, J., \& Vigil-Colet, A. (2017). Exploratory investigation of theoretical predictors of nomophobia using the Mobile Phone Involvement Questionnaire (MPIQ).Journal of Adolescence, 56, 127-135. https://dx.doi.org/10.1016/i.adolescence.2017.02.003

Bianchi, A., \& Phillips, J. G. (2005). Psychological predictors of problem mobile phone use. Cyber Psychology \& Behavior, 8(1), 39-52

Bragazzi, N. L., \& Puente, G. D. (2014). A proposal for including nomophobia in the new DSM-V. Psychology Research and Behavior Management, 7, 155-160. https://dx.doi.org/10.2147/PRBM.S41386

Dongre, A. S., Inamdar, I. F., \& Gattani, P. I (2017). Nomophobia: A study to evaluate mobile phone dependence and impact of cell phone on health. National Journal of Community Medicine, 8(11), 688-693.

Febriana, C., \& Mariyana (2020). Hubungan karakteristik remaja dengan tingkat kecanduan gadget dikota bukittinggi. Real in Nursing Journal, 3(3), 174- 183. http://dx.doi.org/10.32883/rnj.v3i3.1054.g404

King, A. L. S., Valenca, A. M., \& Nardi, A. E. (2010). Nomophobia: The mobile phone in panic disorder with agoraphobia reducing phobias or worsening of dependence?. Cognitive and Behavioral Neurology, 23(1). 52-54. http://dx.doi.org/10.1097/WNN.0b013e3181b7eabc

King, A. L. S., Valenca, A. M., Silva, ACO., Baczynski, T., Carvalho, M. R., \& Nardi, A. E. (2013). Nomophobia: Dependency on virtual environments or social phobia?. Computers in Human Behavior 29(1). 140-144. https://dx.doi.org/10.1016/j.chb.2012.07.025

McCrae, R. R., \& Costa, P. T. (2006). Personality in Adulthood Second Edition A Five-Factor Theory Perspective. New York: The Guilford Press

Nasution, J. A., Neviyarni, S., \& Alizamar. (2017). Motif siswa menggunakan smartphone dan penggunaannya. Jurnal Penelitian Pendidikan Indonesia, 3(2), 15-29. https://dx.doi.org/10.29210/02017114

Okoye, C. A. F., Harry, H. O. N., \& Obikwelu, V. C. (2017). Nomophobia among undergraduate: Predictive influence of personality trait. Practicum Psikologia, $7(2), 64-74$

Prasetyo, A., \& Ariana, A. D. (2016). Hubungan antara the big five personality dengan nomophobia pada wanita dewasa awal. Jurnal Psikologi Klinis dan Kesehatan Mental, 5(1), 1-9.

Rahmania, D. B., \& Prastuti, E. (2021. Peran dimensi kepribadian terhadap nomophobia mahasiswa. Jurnal Sains Psikologi, 3(1). 9-20

Villar, L. A., Grau, J. B., \& Colet, A. V. (2017). Exploratory investigation of theoretical predictor of nomophobia using the mobile phone involvement questionnaire $\begin{array}{lllll}\text { (MPIQ). Journal of } & \text { Adolescence, 56, }\end{array}$ https://dx.doi.org/10.1016/j.adolescence.2017.02.003 
Yildirim, C. (2014). Exploring the dimensions of nomophobia: Developing and validating a questionnaire using mixed methods research. Graduate Theses and Dissertations, 1102.

Yulman. (2018). Kehadiran taman digital menunjang program bukittinggi smart city. Retrieved Maret 6, 2021 from http://bukittinggikota.go.id/berita/kehadirantaman-digital-menunjang-program-bukittinggi-smart-city

Yuwanto, L. (2010). Mobile phone addict. Retrieved Oktober 26, 2020 from https://www.ubaya.ac.id/2018/content/articles detail/10/Mobile-PhoneAd $\backslash$ dict.html 